\begin{tabular}{|c|c|c|}
\hline $\begin{array}{l}\text { EXCELLENT } \\
\text { PURI ISHERS }\end{array}$ & $\begin{array}{c}\text { International Journal of Current Research } \\
\text { and Academic Review } \\
\text { ISSN: 2347-3215 (Online) }\end{array}$ & \\
\hline
\end{tabular}

doi: https://doi.org/10.20546/ijcrar.2017.511.006

\title{
Between River and Sea: What Control a Daily Variation of Physicochemical Properties of Estuary?
}

\author{
Selwa Seif Salum Mchenga ${ }^{1 *}$, Suhaimi Suratman ${ }^{1}$ and Norhayati Mohd Tahir ${ }^{1,2}$ \\ ${ }^{1}$ Institute of Oceanography and Environment (INOS), Department of Chemical sciences, faculty of Science and \\ Technology, University Malaysia Terengganu, 21030 kuala Terengganu, Terengganu, Malaysia \\ ${ }^{2}$ Environmental researches group (ERG), Department of Chemical sciences, faculty of Science and Technology, \\ University Malaysia Terengganu, 21030 kuala Terengganu, Terengganu, Malaysia
}

*Corresponding author

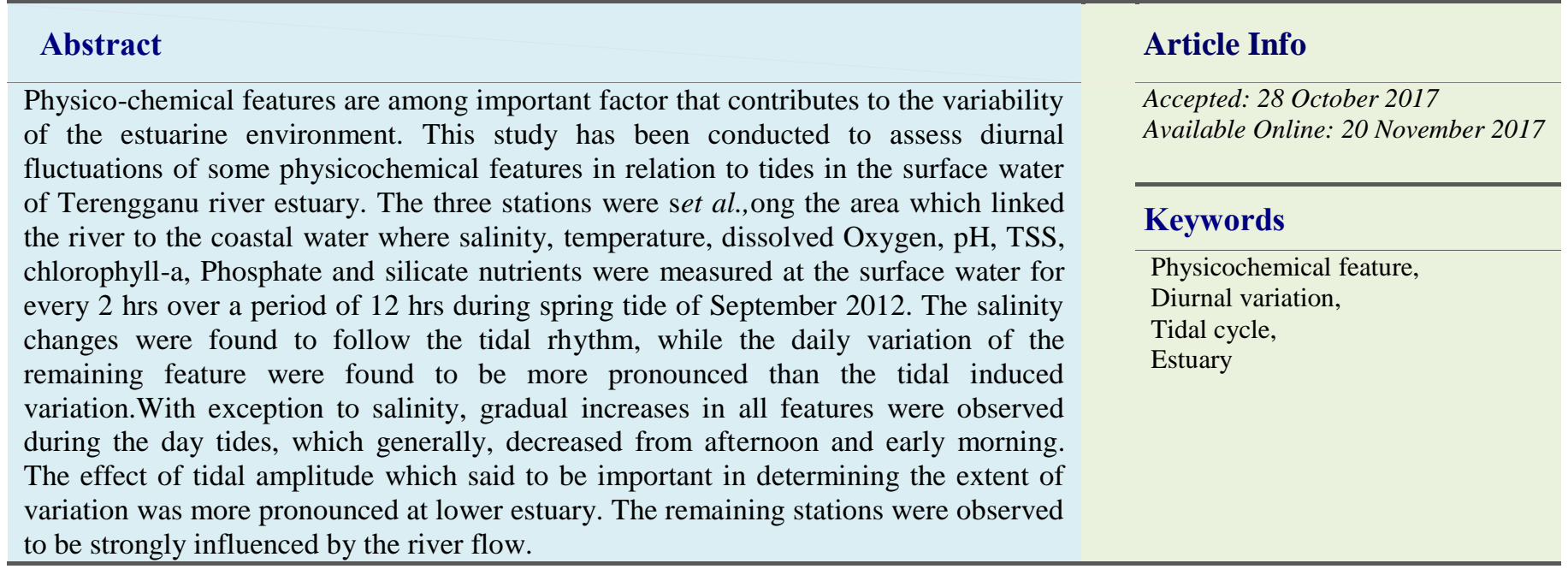

\section{Introduction}

Estuaries are considered to be vital natural resources and unique ecosystems at the interface between terrestrial and marine environments. The environmental conditions of estuaries vary essentially due to the shorttime effects of tidal cycle on the water system. On a time scale of hours, ebb advection of fresh water and salt water intrusion during the flood determine strong changes of several important Physicochemical parameters of the water column such as salinity (Uncles and Stephens, 1996; Toublance et al., 2013), nutrients
(Montani et al., 1998; tahir et al., 2008; Kaniz et al., 2014) and total suspended solids (Bimol et al., 2009; Dayang et al., 2012). The extent of such changes will further vary depending on tidal state or amplitude. Other environmental factors such as precipitation rate, winds and currents velocity of both fresh and sea water may greatly confound the situation, resulting to non-linear interactions between the river flow and the incident open sea hydrodynamics at the mouth and so the physicochemical feature of the system. Information on diurnal variations in physicochemical properties of estuarine system is essential to understand the 
implications of such changes on various processes like biogeochemical cycling of elements and productivity of estuary (Kumar et al., 20001; Toublance et al., 2013). A number of works have been done on chemical and physical characteristics of some Malaysian estuaries (Suratman et al., 1996; Law et al., 1998; Tahir et al., 2008; Jala et al., 2012; Kaniz et al., 2014; Aris et al., 2014). However the studies concerning diurnal variation of such parameters with respect to tides are few. The present work is an attempt to address such variations in the Terengganu river estuary.

\section{Experimental}

The observation was made at Terengganu river estuary, situated on the east coast of peninsular Malaysia facing the South China Sea (Figure 1). The sampling was done during the spring tide to assess the maximum differences in the physicochemical features caused by the tides. The $12 \mathrm{hrs}$ series observation was done on the riverine station (T24), an upper estuarine station (T16) and lower estuary station (T8) set al.,ong the study area. With the help of a tide table, the flood tide and ebb tide were marked out of total $12 \mathrm{hrs}$ period starting from 0800 to $2000 \mathrm{hrs}$.

Surface water temperature, salinity, DO and $\mathrm{pH}$ were insitu measured at each station using the YSI multiparameter. Water samples from the three sampling stations were collected, filtered and brought to the laboratory simultaneously. The filter paper were used to analyse TSS and Chlorophyll-a as directed earlier by APHA 1992 and 1998 respectively. The concentrations of inorganic nutrients (DIP and DISi) in the water samples were analyzed using an auto analyzer (Model: Skalar San++) according to the method of Grasshoff and Koroleff (1983). Total nutrients (TP and TSi) and total dissolved nutrients (TDP and TDSi) were determined using potassium peroxydisulfate oxidation method (Grasshoff and Koroleff, 1983).The dissolved organic nutrients (DOP and DOSi) value was taken as the difference between their total dissolved nutrients and particulate nutrients values (TPP and TPSi) were taken as the difference between their total nutrients. The analytical precision was less $1 \%$ for DIP, TDSi and TPSi and $2 \%$ TDP, TPP and DISi. The measurement and water sample collection were done once in $2 \mathrm{hrs}$ to cover at least one stages of a diurnal tidal cycle.

\section{Results and Discussion}

The results of the tidal cycle and general physicochemical parameters monitored during the survey are shown in figure 2, 3 and 4 respectively. The mean content of each feature relative to tidal fluxes were presented in table 1 and 2 .

\section{Tides}

During the sampling period, at least one lower and one higher tidal levels were predicted (Figure 2). The first high tide, at 1000 , was $+1.9 \mathrm{~m}$ and the expected second high tide, at 2100 , was $+1.5 \mathrm{~m}$. The difference in tidal height was used to distinguish them as a higher and lower flood tide, respectively. Correspondingly, a high low tide occur at 1600 which was $+0.9 \mathrm{~m}$. The largest difference ofthe tidal level was $1 \mathrm{~m}$ between 0800 hrand $2000 \mathrm{hr}$.

\section{Salinity}

The diurnal change in salinity with reference to tide is presented in figure 3(a). During the first $2 \mathrm{hrs}$ of measurements, at high flood tide, a strong salinity gradient was observed among the study locations. Salinity was significantly higher at $\mathrm{T} 8$ located at the lower part of estuary (Table 1).

Following the ebb flow and the low flood tide, fresh water runoff progressively and strongly reduced the salinity at both Stations. The T24 reported $0.00 \mathrm{ppt}$ during the 12 hrs survey which confirmed that this station is a riverine station and experiences no influence from the sea at any tidal point.

The diurnal change in salinity was found to follow ebb and flood condition. High salinity water import was stronger at the high flood tide than the low flood tide. Correspondingly; salt intrusion was stronger at the higher flood tide than at the lower flood tide (Tahir et al., 2008; Toublance et al., 2013). A low-salinity surface water mass moving down-estuary with the ebb tide led to the decrease of salinity, however the effect of fresh water intrusion to estuary was strongest during evening low flood water causing the decrease in salinity to minimum. This implies that only during high flood tide of spring tide the salt water intrusion become more significant.

The observation also suggests a strong influence of both river and sea water amplitude on salinity distribution. This observation is in disagreement with the report of Uncles and Stephens (1996) and Montani et al., (1998) who showed that only salinity intrusion was a strong function of the tidal state and a weaker function of fresh water inflow. 


\section{Temperature}

The fluctuation in temperature along TRE was slightly low between the stations and the tides (figure 3(b)). The maximum difference in temperature with the state of tides was only $0.1^{\circ} \mathrm{C}$ (Table 1). Generally the temperature was observed to be low during the first $2 \mathrm{hrs}$ of high flood tide at the lower part of estuary, increase slightly with the incoming ebb water and decrease with the incoming low flood water. At upper estuary and riverine station, the temperature was measured higher during the two flood phases with slightly low value in ebb tide.

The daily variation of surface water temperature exhibited a maximum value around1400 - 1700 and the minimum value around 0800 and 2000 , thus a gradual increase in temperature was observed during the day tides, which, typically decreased from afternoon and early morning. Similar observation was made earlier by Kaliyamurthy (1976) in Pulicat Lake, Montani et al.,(1998) in tidal estuary of the Seto Inland Sea, and Brasileira and Brasileira (2012)in the estuary of the Jaguaribe river. The authors attributed their results with the daily change in atmospheric temperature.

Sharp drop of temperature observed around 1600 was due to heavy rain in the river. It appears, therefore, that atmospheric condition plays an important role in warming and cooling of the studied area, thus overshadowing the differences brought by the tide (Dehari, 2970; sarma et al., 2010).

\section{Dissolved oxygen (DO)}

The mid-day water carried more oxygen than the morning and late afternoon water (Figure 3(c)). The variations in DO were greater between the stations than the tidal fluctuation. During the early $2 \mathrm{hrs}$ of survey confined to high flood tide, the DO was higher at the lower estuary, intermediate at the upper estuary and slightly low at the river station. The DO concentration starts to decrease with incoming ebb tide and to the maximum at low flood tide down the estuary. The upper estuarine and riverine stations show an increase of DO during ebb tide which decreases in the evening with the surging of low tidal flood.

The DO content of the surface water of Terengganu river estuary was higher during afternoon (1100 - 1600). The high DO in all stations was found to coincide with the peak temperature measured during the survey.
Observations of Qasim and Gopinathan (1969), which showed that the oxygen values began to increase after sunrise and reached the maximum during the early hours of the afternoon, are comparable to the present observations The authors attributed the oxygen changes to the photosynthetic activity of planktonic and benthic plants. Huggins and Anderson (2005) also lend support to the above explanation. Meanwhile, the lower estuary measured a relatively high mean DO than the rest of stations; this would probably be due to the incursion of well aerated seawater or the higher mixing of air and water due to surface-water agitation by wave action and turbulence (Suratman et al., 1996).

\section{pH}

The variations of $\mathrm{pH}$ were wider between the stations and between high flood tide and ebb tide (figure 3(d)). at the first $2 \mathrm{hrs}$ of high flood tide, the surface water $\mathrm{pH}$ was measured low in all stations, the $\mathrm{pH}$ tend to increase with ebb tide and low flood tide at lower estuary. The upper estuarine and riverine stationsreport a surge of $\mathrm{pH}$ with ebb tide which decreases slightly with incoming low flood tide.

There appears a wide range of fluctuation in $\mathrm{pH}$ with regard to tidal stages. The low $\mathrm{pH}$ was observed with flood tide and increased to the maximum with the peak ebb tide. The increase in $\mathrm{pH}$ concedes with the peak temperature (photosynthetic hours) for both stations. The observation of Zhang et al., (2013), which showed that the $\mathrm{pH}$ moved in line with the diurnal trends of temperature, falling to the lowest values at $0600 \mathrm{am}$ and rising to the highest between 12:00 and 15:00, when the temperature reached the peak of the day at Sanya Bay, is comparable to the present observation. The authors attributed the $\mathrm{pH}$ change to the photosynthesis process of biological community. Usually the photosynthetic consumption of carbon dioxide $\left(\mathrm{CO}_{2}\right)$ can drive $\mathrm{pH}$ to high levels, thus $\mathrm{pH}$ may be higher during daylight hours when photosynthesis is at maximum. The major drive of $\mathrm{pH}$ fluctuations between stations was the net photosynthesis, respiration and decomposition process, which probably depend on the relative abundance of biological communities at each location (Dickson, 2010). The time and amount of sewage discharge from the surroundings (Subin and Husna, 2013, which feature the river, and, to some extent the upper estuary, was predicted to lower the relative $\mathrm{pH}$ of these stations. However, the buffering capacity of the estuary (Elliot $e t$ al., 2008) resulting from seawater intrusion produced a comparable $\mathrm{pH}$ at lower part of estuary. 
Table.1 The mean content of salinity, temperature, DO, pH, TSS and Chlorophyll-a relative to tidal fluxes

\begin{tabular}{llccc}
\hline \hline \multirow{2}{*}{ Feature } & \multicolumn{1}{c}{ Tides } & \multicolumn{1}{c}{ Stations } & T24 \\
\cline { 3 - 4 } & & T8 & T16 & $0.00 \pm 0.00$ \\
Salinity (ppt) & Flood* & $26.4 \pm 5.94$ & $0.60 \pm 0.57$ & $0.00 \pm 0.00$ \\
& Ebb & $12.6 \pm 13.9$ & $0.33 \pm 0.58$ & $0.00 \pm 0.00$ \\
\hline \multirow{3}{*}{ Temperature } & Flood & $4.00 \pm 1.41$ & $0.00 \pm 0.00$ & $29.0 \pm 0.07$ \\
& Flood* & $29.5 \pm 0.35$ & $28.7 \pm 0.21$ & $28.7 \pm 1.34$ \\
& Ebb & $29.7 \pm 0.25$ & $28.5 \pm 1.13$ & $29.2 \pm 0.07$ \\
\hline \multirow{3}{*}{ DO } & Flood & $29.3 \pm 0.07$ & $28.7 \pm 0.85$ & $3.69 \pm 0.10$ \\
& Flood* & $5.41 \pm 0.30$ & $3.87 \pm 0.52$ & $3.88 \pm 0.09$ \\
& Ebb & $5.19 \pm 0.50$ & $4.04 \pm 0.26$ & $3.84 \pm 0.07$ \\
\hline \multirow{2}{*}{ pH } & Flood & $4.74 \pm 0.02$ & $3.78 \pm 0.03$ & $6.64 \pm 0.03$ \\
& Flood* & $6.06 \pm 0.33$ & $6.59 \pm 0.30$ & $6.87 \pm 0.55$ \\
& Ebb & $6.11 \pm 0.26$ & $7.12 \pm 0.90$ & $6.48 \pm 0.25$ \\
\hline \multirow{2}{*}{ TSS } & Flood & $6.24 \pm 0.16$ & $7.11 \pm 0.16$ & $17.0 \pm 4.24$ \\
& Flood* & $61.5 \pm 27.6$ & $26.0 \pm 2.83$ & $14.0 \pm 10.5$ \\
\hline \multirow{3}{*}{ Chlorophyll-a } & Ebb & $77.7 \pm 64.4$ & $28.3 \pm 19.6$ & $9.50 \pm 3.54$ \\
& Flood & $25.5 \pm 12.0$ & $18.5 \pm 9.19$ & $6.46 \pm 1.60$ \\
& Flood* & $8.25 \pm 6.79$ & $15.3 \pm 13.7$ & $3.91 \pm 1.60$ \\
\hline \hline
\end{tabular}

* representing the High flood tide.

Table.2 The mean concentrations of DIP, DOP, TPP, DISi, DOSi and TPSi relative to tidal fluxes

\begin{tabular}{|c|c|c|c|c|}
\hline \multirow[t]{2}{*}{ Feature } & \multirow[t]{2}{*}{ Tides } & \multicolumn{3}{|c|}{ Stations } \\
\hline & & T8 & T16 & T24 \\
\hline \multirow{3}{*}{ DIP } & Flood* & $0.31 \square \square 0.01$ & $0.47 \square \square 0.02$ & $0.48 \square \square 0.02$ \\
\hline & Ebb & $0.36 \square \square 0.03$ & $0.48 \square \square 0.05$ & $0.38 \square \square 0.05$ \\
\hline & Flood & $0.36 \square \square 0.01$ & $0.44 \square \square 0.10$ & $0.31 \square \square 0.11$ \\
\hline \multirow{3}{*}{ DOP } & Flood* & $0.27 \square \square 0.01$ & $0.48 \square \square 0.02$ & $0.51 \square \square 0.02$ \\
\hline & Ebb & $0.35 \square \square 0.22$ & $0.59 \square \square 0.25$ & $0.94 \square \square 0.22$ \\
\hline & Flood & $0.79 \square \square 0.36$ & $0.96 \square \square 0.29$ & $0.97 \square \square 0.73$ \\
\hline \multirow{3}{*}{ TPP } & Flood* & $0.52 \square \square 0.02$ & $0.73 \square \square 0.02$ & $1.26 \square \square 0.04$ \\
\hline & Ebb & $0.23 \square \square 0.19$ & $1.41 \square \square 0.54$ & $1.40 \square \square 0.25$ \\
\hline & Flood & $0.76 \square \square 0.60$ & $1.11 \square \square 0.77$ & $1.52 \square \square 1.46$ \\
\hline \multirow{3}{*}{ DISi } & Flood* & 7.751 $\square \square \square \square \square \square$ & 14.45 $\square \square \square \square \square \square$ & 17.95 $\square \square \square \square \square$ \\
\hline & Ebb & $8.083 \square \square \square \square \square \square$ & $12.87 \square \square \square \square \square \square$ & $19.30 \square \square \square \square \square \square$ \\
\hline & Flood & 9.933 $\square \square \square \square \square$ & $10.93 \square \square \square \square \square \square$ & $7.632 \square \square \square \square \square \square$ \\
\hline \multirow{3}{*}{ DOSi } & Flood* & 60.11 $\square \square \square \square \square$ & $289.4 \square \square \square \square \square$ & $105.4 \square \square \square \square \square \square$ \\
\hline & Ebb & 48.29 $\square \square \square \square \square$ & $265.0 \square \square \square \square \square$ & $316.8 \square \square \square \square \square \square$ \\
\hline & Flood & $386.5 \square \square \square \square \square$ & $904.3 \square \square \square \square \square$ & 351.6 $\square \square \square \square \square$ \\
\hline \multirow{3}{*}{ TPSi } & Flood* & $110.5 \square \square \square \square \square \square$ & 155.9 $\square \square \square \square \square \square \square$ & $167.8 \square \square \square \square \square$ \\
\hline & Ebb & $212.4 \square \square \square \square \square$ & $105.0 \square \square \square \square \square \square$ & 82.93 $\square \square \square \square \square$ \\
\hline & Flood & 209.3 $\square \square \square \square \square \square$ & $121.4 \square \square \square \square \square$ & 209.2 $\square \square \square \square \square \square$ \\
\hline
\end{tabular}

* representing the High flood tide. 
Fig.1 Study area and location of sampling station along Terengganu river estuary: T8 (Lower estuary), T16 (Upper estuary) and T24 (river station)

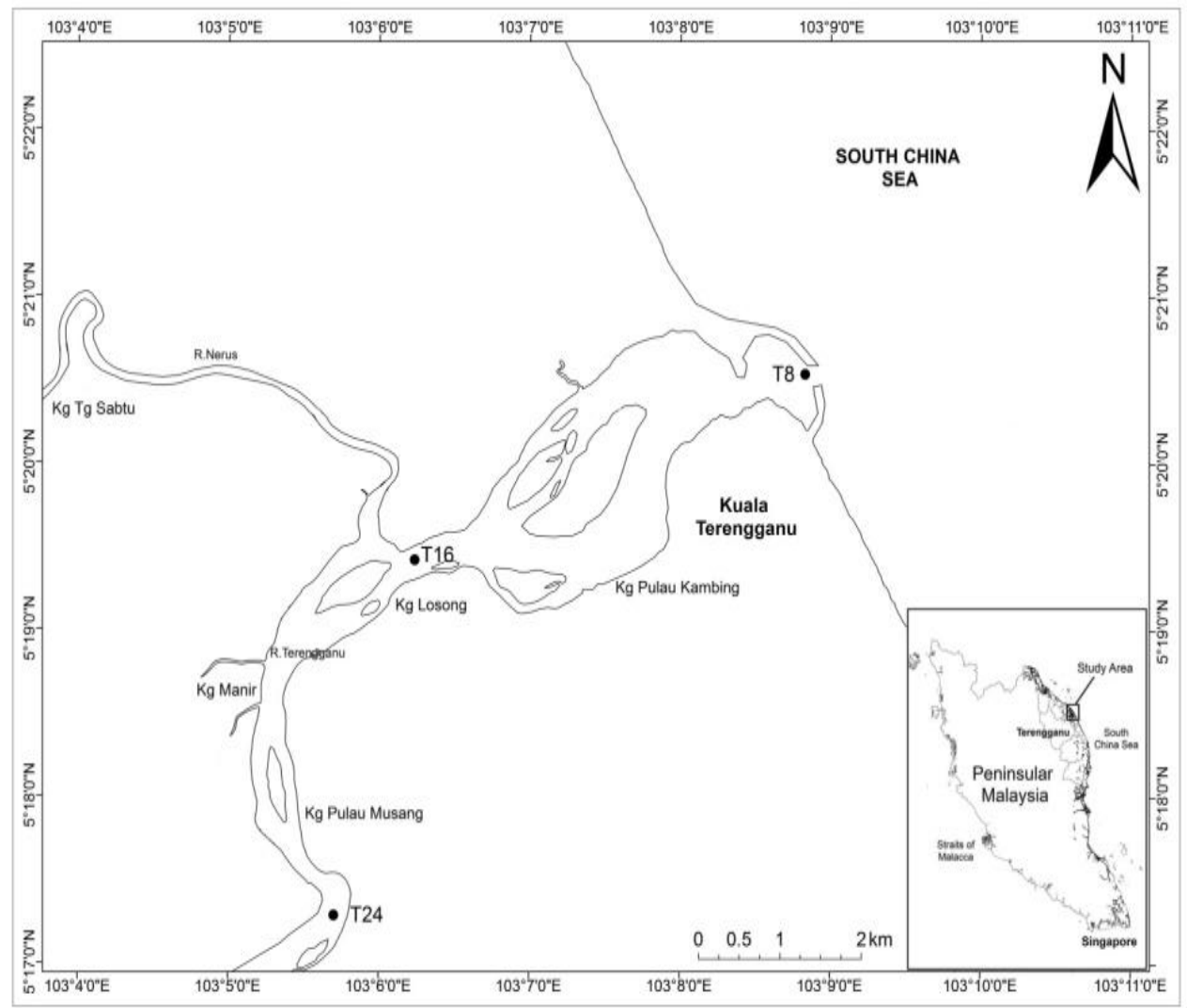

Fig.2 Spring tide cycle during 12 hours survey of September 2012

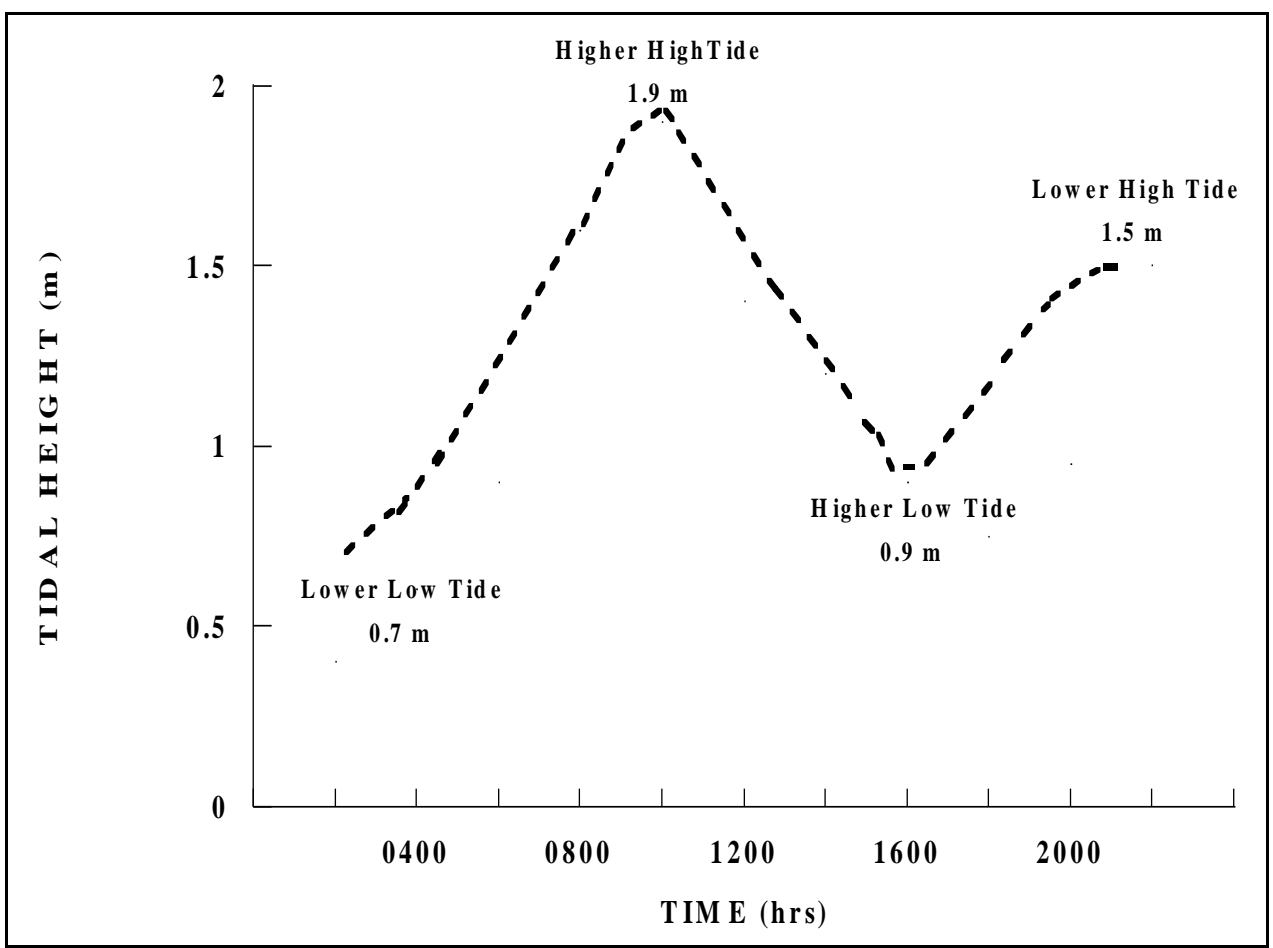


Fig.1 Diurnal variation of salinity (a), surface water temperature (b), DO (c), pH (d), TSS (e) and chl a (f)

(a)

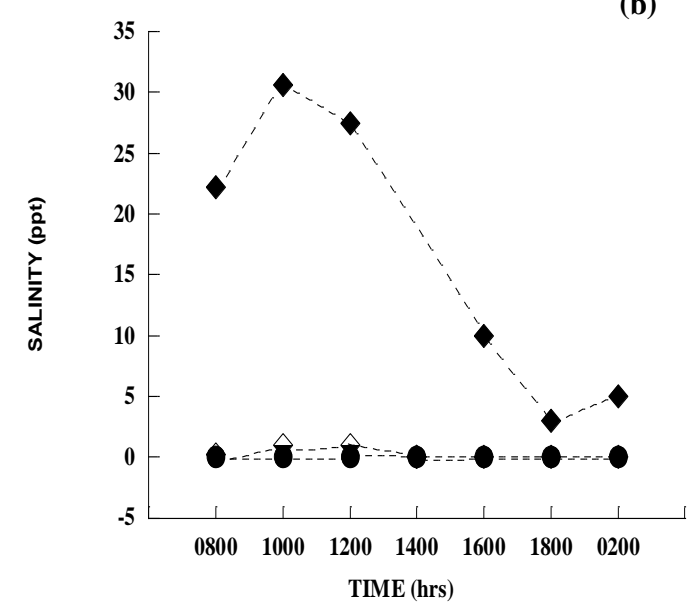

(c)

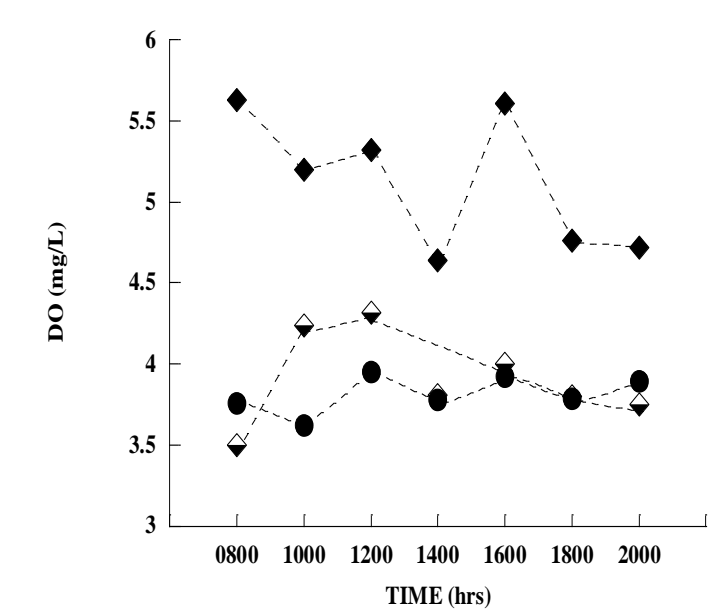

(e)

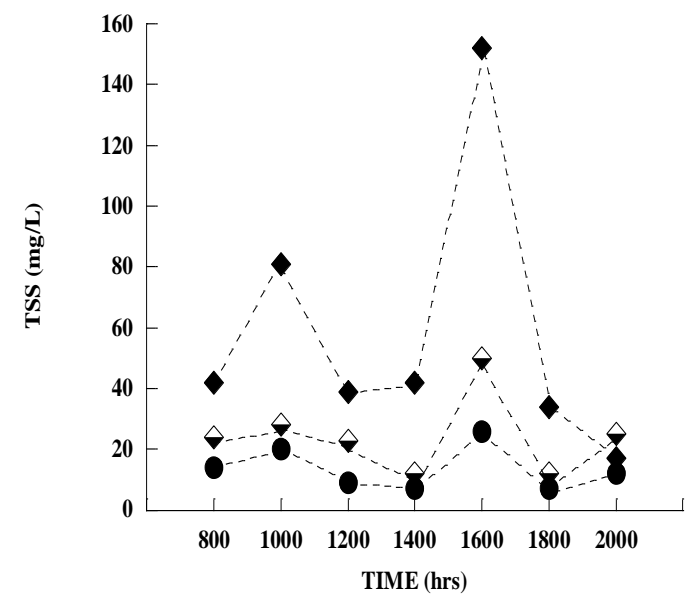

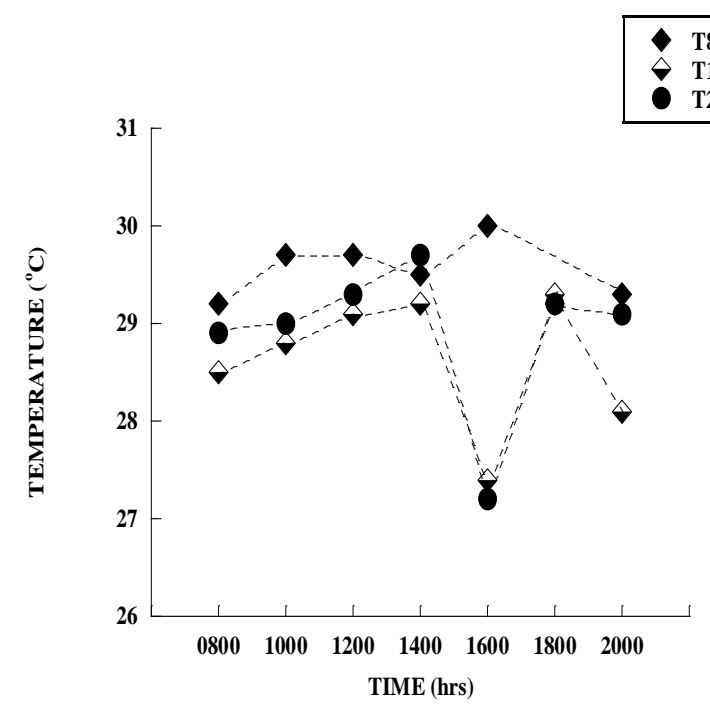
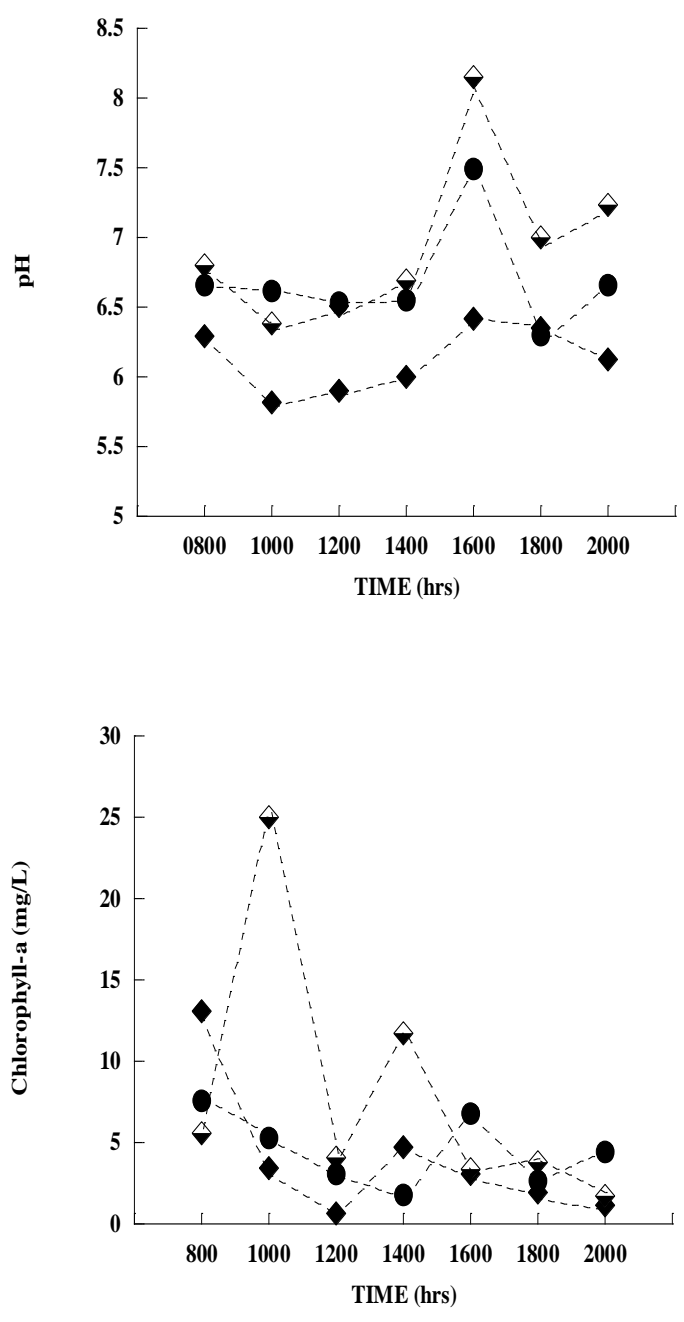
Fig.2 Diurnal variation of phosphate and silicate nutrients along TRE

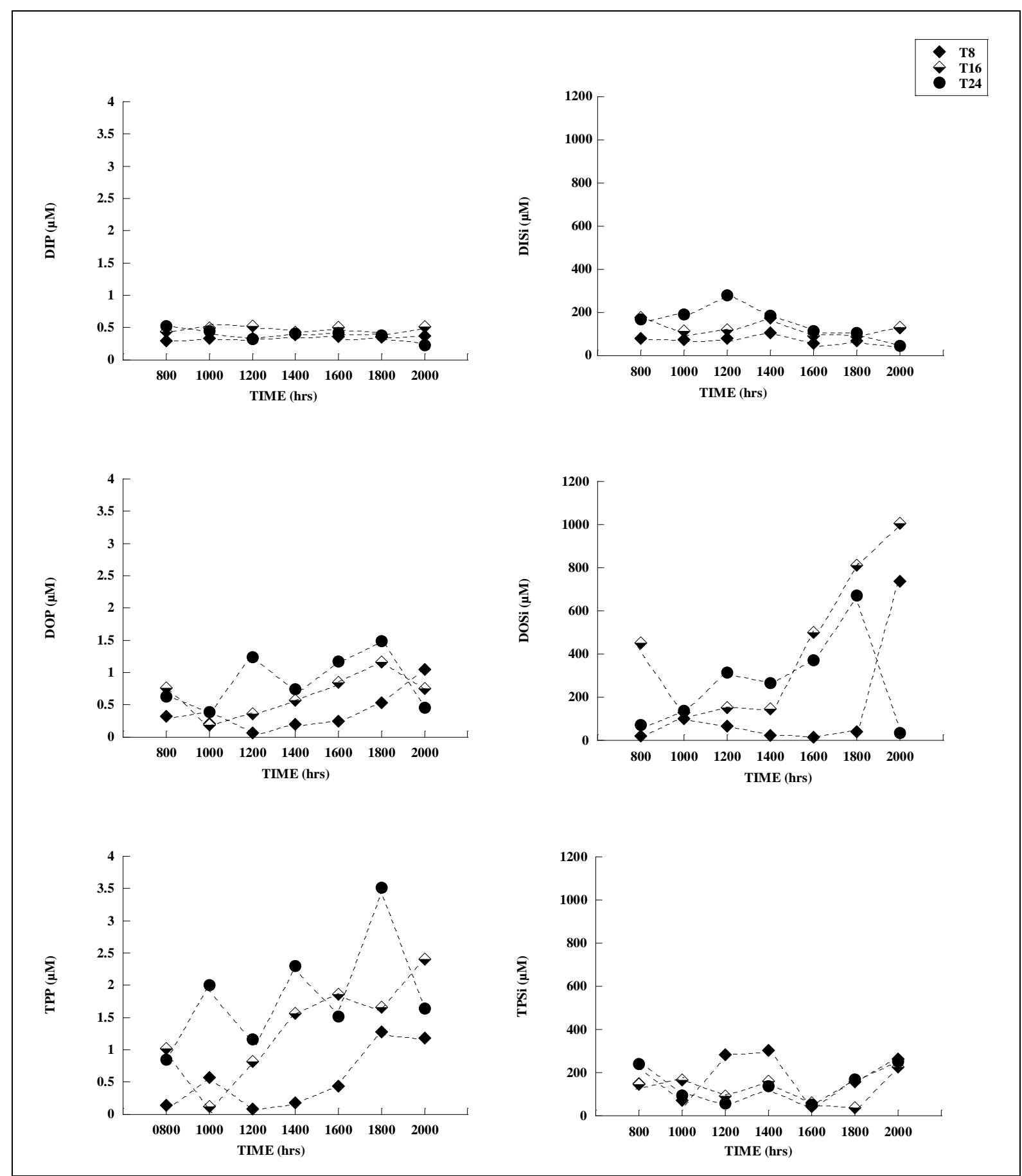

TSS

The marked diurnal variations in TSS content with reference to tide were observed (Figure 3(e)). In the first 2 hrs of measurements, at high flood tide, the mid-mean values of TSS concentration was observed in all stations. The concentration was observed to increase at lower and upper estuary during ebb tide, followed the decrease at the riverine station. The TSS was then decrease to the minimum in all stations during the low flood water.

In hourly time scale the tidal advection under the ebb and flood tide conditions transport freshwater and salt water to the estuary, which results in a strong diurnal change in 
TSS content. The TSS concentrations were more during ebb tide than the flood tide, this indicate that the influx of TSS into this estuary is seaward, which principally depends on the river flow. The result is in agreement with those reported at Itajai-Acu estuary (Schettini and Carvalho, 1998), Caboriuestuary (Siegle et al., 2009) and Manggatalestuary (Yusop, 2007). Thus far the TSS was found higher at the high water of the flood tide than for the low flood tide. This observation attributed to the resuspension of the bottom sediments caused by strong currents generated from the large tidal range during high flood of spring tide. Similar observation was reported elsewhere by Suratman et al., (1996) at Selangor River, Bimol et al., (2009) at Sempadi river estuary and DayangSiti Maryam (2012) at Manngatal estuary.

\section{Chlorophyll-a}

In the first $2 \mathrm{hrs}$ of high water of the flood tide, the concentrations of chlorophyll-a were higher at all stations and decreased gradually with the incoming ebb tide and low water of the flood tide (figure 3f)). However, the T16 and T24 showed a higher concentration than the T8 station suggesting that the spreading of this pigment is seaward.

A number of studiesthat examined the diurnal change of chlorophyll-a withthe tide have been conducted. For example Yin and Harrison (2000) reported a higher chlorophyll-a content during the flood tide than the ebb tide, indicating a loss of the pigment from the water column, which was likely due to feeding by benthic organisms. Naik et al., (2012), however, related this observation to the species diversity and phytoplankton density, which seemed to increase and decrease with the flood and ebb water, respectively. Although the same trend has been observed in the present study, the justification provided by the two aforementioned studies was slightly inappropriate for the scenery; it is thought that the tidal mixing of water or resuspension of phytoplankton from surface sediment, particularly during the high flood tide, results in high chlorophyll-a content in the surface water. This phenomenon has been well explained earlier by Qasim and Gopinathan (1969), Anderson et al., (1983) and Shikata et al., (2008). Further observation show the diurnal peaks of chlorophyll-a during the daytime than the night. This may be because of the ambient temperature and light at daytime are among the important parameters for their production peaks in the day hours, which decreased to the minimum during the late hours of the evening (Qasim and Gopinathan, 1969 and Senthilkumar et al., (2008).

\section{Phosphate}

The average values of each $\mathrm{P}$ species relative to the sampling stations and their diurnal trend were shown in Table 2 and figure 3 respectively. During the first two hours of peak flood, the DOP, DIP and TPP were lower at $\mathrm{T} 8$. The trend was reversed during the ebb tide. With the low water of the flood tide the concentration of each species increased relatively to the $\mathrm{P}$-surge from the river. Relative to this observations, the river water seemed to be a major source of all P-species to the estuary and the transportation of this nutrient relied more on the river flow rather than the tidal cycle; however, the minimal influence of the tide that was observed during the high water of spring tide at $\mathrm{T} 8$ was influenced by the $\mathrm{P}$ fluctuation from T16, which interconnects the two rivers and estuary. The increase in the P content at T16 might directly or indirectly come from T24 since the two stations were quite far from each other, thus the river flow intensity must be there to ensure the supply of Pspecies at T16. T24 became an independent station with respect to T16 and T8. For the three stations, T16 and T24 seemed to possess more $\mathrm{P}$ than the rest suggesting the retention of this nutrient, which then became an essential source downstream.

The fluctuations in the phosphate levels seemed to be more perturbing. Lillebø et al., (2002) reported a higher $P$ efflux during the first hour of tidal flood with a sharp or linear decrease at high tide and incoming ebb phase. The authors explain his observation that, the higher phosphate efflux rates in the first hours may result from the contact of the incoming seawater, with lower phosphate concentration and lower temperature, with the rich warm superficial (low tide pools) or interstitial water. These differences of P-content between the two waters may promote the phosphorus efflux to the incoming water column by diffusion and/or convection process. The differences will be attenuated as the tide comes in, and phosphate efflux rates smoothly decrease. During the tidal ebb, the efflux rates showed a sharp, sometimes linear decrease. This is because the airexposed sediments have a substantially higher phosphate sorption capacity than the submerged sediments, thus reducing the P-content from the low water ephemeral pools formed. In contrast, Naik et al., (2012) found an increase in the $\mathrm{P}$ concentration during the ebb phase, with an inverse relationship between salinity and Pnutrient, suggesting that the increase in P-nutrient at this tidal point was due to river input. In respect of the Terengganu River estuary, the ebb-flood change in Pnutrient might probably be affected by river flow. 
However, the high $\mathrm{P}$ reported during the high water of the flood tide could be attributed to the resuspension of the surface sediments resulting in its high concentration at the surface water.

\section{Silicate}

The DOSi, DISi and TPSi were found to be lower at T8, the trend was reversed for DISi and TPSi during the ebb tide of the first two hours of sampling. The DOSi tends to decrease following its decrease at T16. Temporarily, the riverine stations reported higher content of Si-species in the flood and ebb phase. With the coming low tide of high water, the DISi at T8 was observed to increase with a decrease from T16 and T24 while DOSi and TPSi increased with the increase of the concentration at T16 and T24 (figure 3).

The general observation of diurnal variation of $\mathrm{Si}$ in the study area shows no clear-cut relation between the Silicate concentration and tidal phase. Observation of Kumar et al., (2000) showed both high and low concentrations during all tidal phases in the Mulki Estuary, which is comparable to the present surveillance. The authors concluded the absence of a relationship between the two variables ( $\mathrm{Si}$ and tidal rhythm). In addition, the river stations showed a higher $\mathrm{Si}$ concentration than the estuary. This observation comes from the fact that the rivers are the major vectors of large-scale redistributions of $\mathrm{Si}$ between continents and the ocean via estuaries, transporting large quantities to marine waters (Tre'guer and De La Rocha 2013; Carey and Fulweiler, 2014). Apart from weathering, which is known to be the ultimate source of silica for the river and estuaries, human activity can add to the observed high $\mathrm{Si}$ in the study area. Conley et al., (2008) reported that landuse activities have an influence on $\mathrm{Si}$ concentrations in adjacent rivers. In the Terengganu River estuary, the most forested watersheds are those of the Nerus and Terengganu Rivers with the largest surface area devoted to agriculture. Although the impact of the agriculture on the water geochemistry differs strongly from one stream to another its impact seemed to be high in the Nerus River since both cultivated crops and pasture land (included in grasslands) are the biomes of most $\mathrm{Si}$ sequestration. Urbanization and development may also affect the riverine $\mathrm{Si}$, particularly DSi concentrations that come from partially treated sewage systems and wastewater enriched in DSi due to the use of washing powders (Meunier et al., 2011); this is featured in Terengganu River and its estuary. Other features like sand digging, sand embankments and the presence of water treatment plan dragging, may also be superimposed, translating into high $\mathrm{Si}$ content in the area.

The freshwater inflow along Terengganu river estuary was a vital course of estuary physicochemical properties dynamics as indicated by the strong changes of all features at individual stations on a time scale of $2 \mathrm{hrs}$. The effect of the tidal amplitude was observed at lower estuary merely at high tide of spring tide. The higher values of nutrients in riverine stations suggest that, the river can be an important source on nutrients for the estuary and adjacent sea.

\section{Acknowledgment}

This study was supported by grant awarded by National Hydraulic Research Institute of Malaysia(NACHRIM)(Grant Vote No 53112) and by the higher institution Centre of excellence (HICoI), Research grant (Vote No. 66928). Thanks to Dr Islam S.S. Mchenga for editorial and scientific comments.

\section{References}

Anderson, D. M., Chisholm, S. W., \&Watras, C. J. (1983).Importance of life cycle events in the population dynamics of Gonyaulaxta marensis. Marine Biology. 76, 179-189.

APHA. (1992). Standard Methods for the Examination of Water and Wastewater, $\left(18^{\text {th }} \mathrm{ed}\right)$. American Water Works Association, Water Environment Federation. Method 4500-E.

APHA.(1998). Standard methods for the examination of water and wastewater.20th edition. New York, The United State of America. (Pp.1067).

Aris, A.Z., Lim,W.Y., Praveena, S.M., Yusoff, M.K., Ramli, M.F. andJuahir, H. (2014). Water Quality Status of Selected Rivers in Kota Marudu, Sabah, Malaysia and its Suitability for Usage. Sains Malaysiana 43(3) (2014): 377-388.

Bimol,M., Ling, T.Y., Nyanti, L., Norhadi, I. and Emang, J.J.J. (2009). Total Suspended solids variation during high/low tide of spring tide along Sampadi River, serawak.Proceeding of the $3^{\text {rd }}$ Regional conference on natural Resources in the Tropics (NRTrop3).

Brasileira, Revita and SociedadeBlasileira. (2012). Spatial and temporal variability of hydrographic parameters measured in the estuary of the Jaguaribe river (Semi-arid region, Northeast, Brazil). 30: 245 -61 . 
Carey, J. C. \&Fulweiler, R. W. (2014). Salt marsh tidal exchange increases residence time of silica in estuaries. Limnology and Oceanography. 59(4), 1203-1212.

Conley, D. J., Likens, G. E., Buso, D. C., Saccone, L., Bailey, S. W., \& Johnson, C. E. (2008). Deforestation causes increased dissolved silicate losses in the Hubbard Brook Experimental Forest. Global Change Biology. 14(11), 2548-2554.

DayangSiti Maryam.,Ejria, S. and Than, A. (2012). Water fluxes, suspended solid distribution and water properties in the mouth of Menggatal estuary, Kota Kinabalu, Malaysia. Journal of topical biology and conservation. 9(1), $1-13$.

Dehadrai, P. V. (1970). Changes in the environmental features of the Zuari and Mandovi estuaries in relation to tides. Proceedings of the Indian Academy of Science, and 2B, 68-80.

Dickson, A.G. (2010). The Carbon Dioxide System In Sea Water: Equilibrium Chemistryand Measurements. In: Riebesell, U., Fabry, V.J., Hansson, L., Gattuso, J.-P. (Eds.). Guide to best practices for ocean acidification research and data reporting. Publications office of the European Union, Luxembourg, Pp. 17- 40.

Elliot, M., Boyes, S.J. and Burdon, D. (2008). A scientific understanding of the Tees Estuary to determine the cause of macroalgal mats at seal sands. Report by: Institute Of Estuarine and Coastal Studies (IECS). University of Hull.Prepared for the Environmental Agency and Northumbrian Water Ltd.

Grasshoff, K., \& F. Koroleff.(1983). Determination of nutrients. In Methods of Seawater Analysis, K. Grasshoff, M. Ehrhardt, \& K. Kremling (eds). Verlag Chemie Publisher. (Pp. 125 - 187).

Huggins. G. D. and Anderson, J. (2005). Dissolved oxygen fluctuation regimes in streamsof the Western Corn Belt Plains Ecoregion.University of Kansas.

Jalal, K.C.A., Noor Faizul, H.N., AzrulNaim, M., John B. A. andKamaruzzaman, B.Y. (2012). Study on water quality and pathogenic basteria in coastal water Langkawi, Malaysia.JEnviron.Biol. 33, 831835.

Kaliyamurthy, M. (1976).Changes in the environmental features of Pulicatelake in relation to tides.Indian. J. Fish., 23(1-2): 111-119.

Kaniz, F., Wan Maznah, W. O. and Mansor, M. I. (2014).Spatial and Temporal Variation of Physicochemical Parameters in the Merbok Estuary, Kedah,
Malaysia.Tropical Life Sciences Research, 25(2), 119, 2014.

Kumar, S. V., Rajesh, K.M. and Menon, M.R. (2000).Diurnal variation of nutrients in relation to tidal rhythm of Mulki Estuary, South West Coast of India.J.Inland Fish.Soc. India. 32(2), 57 - 62.

Law, A.T., Mohd, N.S., Khuswant, S. A.L., Charan, S. and Jong, K.J. (1998). Petrolium hydrocarbon and sewage pollution in the Terengganu River and its estuary. A paper presented at the Malaysian Science and Technology Congress 98. 7-9 November, Terengganu.

Lillebø, A. I., Pardal, M. A., Flindt, M. R., Neto, J. M., Macedo, F., Martins, I., \& Marques, J. C., (2002). Nutrient dynamics in the intertidal pools of the Mondego estuary: Possible contribution to dissolved inorganic phosphorus loading. In: Pardal, M. A., Marques, J. C., \&Gracxa, M. A. (eds.), Aquatic Ecology of the Mondego River Basin. Global Importance of Local Experience.Imprensa da Universidade de Coimbra, Coimbra. (Pp. 287 300).

Meunier, J., Braun, J., Riotte, J., Kumar, C., \&Sekhar, M. (2011).Importance of weathering and human perturbations on the riverine transport of Si.Applied Geochemistry.26, S360 - S362.

Montani, S., Magni, P., Shimamoto, M., AbeN.and K. Okutani. (1998). The effect of a tidal cycle on the dynamics of nutrients in a tidal estuary in the Seto Inland Sea, Japan. J. Oceanogr., 54, 65-76.

Naik, U. G., Nayak, V. V., \&Kusuma, N. (2012).Diurnal Variation of Phytoplankton in the Kali Estuary, Karwar, West Coast of India.Indian Journal of Ecology. 39(1), $52-57$.

Qasim, S.Z. and Gopinathan, C.K. (1969).Tidal cycle and the environmental features of Cochin backwater (A tropical estuary). Pros. Indian Acad. Sci. 69(6), 336-348.

Sarma, V. V. S. S., Prasad, V. R., Kumar, B. S. K., Rajeev, K., Devi, B. M. M., Reddy, N. P. C., Sarma, V. V. and Kuma, M. D. (2010). Intraannual variability in nutrients in the Godavari estuary, India. Cont. Shelf Res. 30, 2005-2014.

Schettini, C. A. F. and Carvalho, J. L. B. (1998).Suspended sediment balance in the estuary of Itajaí-Açuriver during a low discharge period. An. Acad. Bras. Ciênc., 70(2), 325-334.

Senthilkumar, B., Purvaja, R., \&Ramesch, R. (2008). Seasonal and tidal dynamics of nutrients and chlorophyll a in a tropical mangrove estuary, southeast coast India. Indian Journal of Marine Sciences. 37(2), $132-140$. 
Shikata, T., Nagasoe, S., Matsubara, T., Yoshikawa, S., Yamasaki, Y., Shimasaki, Y., Oshima, Y., Jenkinson, I. R. \&Honjo, T. (2008).Factors influencing the initiation of blooms of the raphidophyte Heterosigma akashiwo and the diatom Skeletone macostatum in a port in Japan. Limnology and Oceanography. 53, 2503-2518.

Siegle, E., Schettini, C. A. F., Klein, A. H. F., and ToldoJr, E. E. (2009). Hydrodynamics and suspended sediment transport in the Camboriú estuary - Brazil: Pre jetty conditions. Brazilian Journal Oceanography, 57(2), 123-135.

Spinetti, R. (2012). The diurnal pattern of dissolved oxygen content in natural vs. altered streams in the Dog River watershed.

Subin, M.P. and Husna A.H. (2013). An assessment on the impact of waste discharge on water quality of Priyar River lets in certain selected sites in the northern part of Ernakulum district in Kerala, India. Int. Res. J. Environment Sci. 2(6), 76-84.

Suratman, S., Tahir, N.M. and Loong, T.S. (1996).Tidal Variation of some Physico - chemical and nutrients parameters in Selangor river estuary. Malays.J. of Anal.Sci.. 2(2), 317 - 326.

Suratman, S., Tahir, N.M., Lee, C. Y. and Rashid, S.R.A. (2006).Kesan monsun kepada kualiti air di lembangan Sungai Besut, Terengganu. Malaysian Journal of Analytical Sciences.10, 143-148.

\section{How to cite this article:}

Selwa Seif Salum Mchenga, Suhaimi Suratman and Norhayati Mohd Tahir. 2017. Between River and Sea: What Control a Daily Variation of Physicochemical Properties of Estuary? Int.J.Curr.Res.Aca.Rev. 5(11), 30-40.

doi: https://doi.org/10.20546/ijcrar.2017.511.006
Tahir, N.M., Suratman.S., Shazili, N. M., Ariffin, M.M., Mohd Amin, M. S., NikIskandar Ariff, NFM and Wan Sulaiman, WNH.(2008). Behaviour of water quality parameters during ebb tide in Dungun river estuary, Terengganu. Journal of Sustainability Science and Management. 3(1), 1-10.

Toublanc, F., Brenon, I., Coulombier, T.and Moine, O. (2013). Salinity and suspended sediment dynamics in response to forcing changes in a small macrotidal estuary (Charente, France).Coastal Dynamics.

Tréguer, P. J., \& De La Rocha, C. L. (2013).The world ocean silica cycle.Annual Review of Marine. Science. 5, $477-501$.

Uncles, R. J. and J. A. Stephens 1996.Salt intrusion in the Tweed Estuary. Estuar., Coast. Shelf Sci., 43, 271-293.

Yin, K., \& Harrison, P. J. (2000).Influences of flood and ebb tides on nutrient fluxes and chlorophyll on an intertidal flat. Marine Ecology Progress Sereis. 196, $75-85$.

Yusop, N. M. (2007). Suspended sediment and water fluxes in Menggatal river mouth. Disertasis arjanasains. Uneversiti Malaysia Sabah. Malaysia.

Zhang, C., et al., 2013. Diurnal and seasonal variations of carbonate system parameters on Luhuitou Fringing Reef, Sanya Bay, Hainan Island, South China Sea. Deep-Sea Res. 